Ege Tıp Dergisi / Ege Journal of Medicine 2021; 60 (1): 39-50

\title{
Ferulik asitin lipopolisakkaridaz ile induklenmiş insan lösemi monositik hücrelerinde sitokin salınımına etkisi
}

\section{Effect of ferulic acid on cytokine release in human leukemia monocytic cells induced with lipopolysaccharides}

\begin{tabular}{|c|c|c|c|}
\hline Şahin Öztürk ${ }^{1}$ & Burak Durmaz ${ }^{1}$ & Hikmet Memmedov ${ }^{1}$ (D) & Latife Merve Oktay² \\
\hline Selvi Nur Günel ${ }^{2} \mathbb{D}$ & Murat Olukman ${ }^{3}$ & Eser Yıldırım Sözmen ${ }^{1}(\mathbb{D}$ & \\
\hline${ }^{1}$ Ege Üniversitesi T & kültesi, Tıbbi Biyokir & Anabilim Dalı, İzmir, Türki & \\
\hline e Üniversitesi T & ültesi, Tıbbi Biyc & abilim Dalı, İzmir, Türkiye & \\
\hline
\end{tabular}

\section{Öz}

Amaç: Makrofajlar doğal immün cevabı başlatan ve patojenle ilk temasta bulunan hücreler olarak kabul edilmektedir. Hem hücreler arası ilişkiler hem de inflamatuar mediyatörlerin salınımı yoluyla doğal immün ve inflamatuar yanıtta etkin rol oynamaktadırlar. Insan THP-1 lösemi monositik hücreleri, makrofajların in vitro olarak fonksiyonlarını, mekanizmalarını ve sinyal yollarını araştırmak için en çok kullanılan hücre dizisidir. Lipopolisakkarit makrofaj farklılaşmasını başlatmak için yaygın olarak kullanılan uyarıcılar arasında yer almaktadır. Ferulik asidin, indüklenebilir nitrik oksit sentaz, kaspazlar ve siklooksijenaz (COX)-2 dahil olmak üzere proinflamatuar sitokinlerin ekspresyonunu ve/veya aktivitesini inhibe ettiği bilinmektedir. Bu çalışmada, lipopolisakkarit ile indüklenen THP-1 monosit hücrelerinde Ferulik asidin sitokin (COX-1, IL-la, IL-1 $\beta$, TNF- $\alpha$, IL-6, IL-10, NF-k $\beta$ ve IFN-y) düzeyleri üzerindeki etkisini araştırmayı amaçladık.

Gereç ve Yöntem: TNF alfa seviyeleri farklı konsantrasyonlarda ve zamanlarda LPS eklenerek ölçüldü ve en uygun konsantrasyon ve süre belirlendi. COX-1, IL-la, IL-I $\beta$, TNF- $\alpha$, IL-6, IL-10, NF-k $\beta$ ve IFN-y'nin sitokin miktarları, inkübasyon sürelerinin sonunda toplanan süpernatanlarda ELISA ile ölçüldü.

Bulgular: Ferulik asidin, NF-k $\beta$ inhibisyonu ile lipopolisakkarit ile indüklenen THP-1 hücrelerinde artan TNF- $\alpha$, IL-la ve IL-I $\beta$ ekspresyonunu inhibe ettiğini bulduk.

Sonuç: Ferulik asidin LPS ile indüklenen THP-1 hücrelerinde sitokin salınımı üzerindeki etkisinin gösterilmesi, aşırı inflamatuar yanıtın tedavisinde ve oto-immün hastalıklara karşı korunmada etkili olabileceğini düşündürdü

Anahtar Sözcükler: THP-1 hücreleri, sitokin, lipopolisakkarit, makrofaj hücreleri.

\footnotetext{
ABSTRACT unclear.

Sorumlu yazar: Burak Durmaz

Ege Üniversitesi Tıp Fakültesi, Tıbbi Biyokimya Anabilim Dalı,

İzmir, Türkiye

E-posta: burakdurmaz108@gmail.com

Başvuru tarihi: 20.10.2020 Kabul tarihi: 30.11 .2020
}

Aim: Macrophages are accepted as cells that initially contact with the pathogens and initiate the innate immune response. They play effective roles in innate immune and inflammatory responses by intercellular relations and inflammatory mediator secretion. Human THP-1 leukemia monocytic cells are frequently used for the in vitro determination of the signal pathways, and the functions of macrophages. Lipopolysaccharide is commonly used to induce macrophage differentiation of monocytic cell lines but the extent of differentiation in comparison to primary tissue macrophages is 
Ferulic acid (FA) is known to inhibit the expression and / or activity of proinflammatory cytokines, including inducible nitric oxide synthase, caspases, and cyclooxygenase (COX)-2. In this study, we aimed to investigate the effect of Ferulic acid on cytokine (COX-1, IL-1 $\alpha, I L-1 \beta, T N F-\alpha, I L-6, I L-10, N F-$ $k \beta$ and IFN- $y$ ) levels in lipopolysaccharide induced THP-1 monocyte cells.

Materials and Methods: TNF alpha levels were measured by performing applications at different concentrations and times, and the most appropriate concentration and duration were determined. Cytokine levels of COX-1, IL-1 $\alpha, I L-1 \beta, T N F-\alpha, I L-6, I L-10, N F-k \beta$ and IFN- $\gamma$ were measured by ELISA in supernatants collected at the end of incubation times from wells.

Results: We have found that ferulic acid inhibits the expression of TNF- $\alpha, I L-1 \alpha$ and IL-1 in LPSinduced macrophages by inhibition of NF-kB.

Conclusion: It has been found that the effect of ferulic acid on cytokine release in LPS-induced THP1 cells may be effective in the treatment of excessive inflammatory response and protection against auto-immune diseases.

Keywords: THP-1 cell, cytokine, LPS, macrophage cell.

\section{GíRiş}

Ferulik asit (Trans-4-hidroksi-3-metoksisinnamik asit; FA; moleküler ağılık 194.18) fenolik asitler ailesindendir ve sebze, meyve ve kahve gibi bazı içeceklerde yaygın olarak bulunur (1). Düşük toksisiteye sahip olan ferulik asit (FA) insan vücudunda absorbe edilebilir ve kolayca metabolize edilebilir (2). Oral alımdan sonra FA hızla emilir ve 30 dakika içinde pik plazma konsantrasyonuna ulaşır (3). Yapılan çalışmalar, FA'nın serbest radikalleri temizleyerek ve sitoprotektif sistemlerin düzenlenmesi yoluyla hücre stres yanıtını artırarak güçlü bir antioksidan görevi yaptığını göstermiştir. Hem serbest formda bulunur hem de lignin ve diğer biyopolimerlere kovalent olarak bağlanır. Fenolik çekirdeği ve uzatılmış bir yan zincir konjugasyonu nedeniyle, kuvvetli antioksidan potansiyeli bulunmaktadır. Ayrıca FA'nın, indüklenebilir nitrik oksit sentaz, kaspazlar ve siklooksijenaz-2 dahil olmak üzere bir çok proinflamatuar sitokinlerin ekspresyonunu ve/veya aktivitesini inhibe ettiği gösterilmiştir. Antioksidan özelliklerine dayanılarak, FA Alzheimer hastalığı, kanser, kardiyovasküler hastalıklar, diabetes mellitus ve cilt hastalığı gibi birçok hastalık için potansiyel bir tedavi olarak önerilmiştir. Ferulik asidin hücre büyümesini ve çoğalmasını düzenleme, serbest radikalleri temizleme, sitoprotektif enzimleri uyarma ve sitotoksik sistemleri hem in vitro hem de in vivo deneysel olarak inhibe etme kabiliyeti nedeniyle, kanser tedavisinde potansiyel adjuvan rol oynadığı öne sürülmüştür $(4,5)$.

İnflamasyon, yabancı moleküllere karşı organizmanın ilk cevabıdır (6). Makrofajlar, mikroorganizmaları ve ölü hücreleri tanıdıkları ve İnterlökin-1 (IL-1), TNF- $\alpha$, İnterlökin-6 (IL-6), Prostaglandin E2 (PGE2) ve nitrik oksit (NO) gibi çeşitli proinflamatuar aracılar ürettikleri için bu sürecin başlangıcında büyük rol oynamaktadır (7). Bu aracılar endotel hücrelerini aktive eder ve patojene karşı savaşan ve daha fazla inflamatuar molekül üreten monositler ve nötrofiller gibi daha fazla hücrenin gelişine izin verir (8-10). Makrofajların Toll benzeri reseptör (TLR) dahil olmak üzere farklı patojen tanıma reseptörleri vardır (11). Lipopolisakkarit (LPS), TLR4 tarafından tanınır ve nükleer faktör NFk- $\beta$, aktivatör protein 1 ve interferon düzenleyici faktörler gibi transkripsiyon faktörlerini, NF-k $\beta^{\prime} n ı n$ aktivasyonuna ve proinflamatuar sitokin üretimine yol açan bir sinyal yolu ile veya Miyeloid farklılaşma birincil yanıt geni 88 (MyD88) aracılığıyla aktive eder (12).

Sitokinler, bağışıklık sisteminde ağ iletişimi için gerekli olan önemli aracı proteinleridir. Proinflamatuar ve anti-inflamatuar etkileri olan sitokinler, lenfositler (Lenfokinler) veya monositler (Monokinler) tarafından üretilirler. Kemotaktik aktiviteye sahip sitokinler kemokinler olarak adlandırılır. Proinflamatuar sitokinler (IL-1 $\beta$, IL-2, TNF-alfa, IL-6, IL-8, IFN- $y$ ) ve antiinflamatuar sitokinler (IL-10, IL-4, TGF TG) arasındaki dengenin, immün yanıt homeostazında ve birçok hastalığın nedeni olarak gösterilen inflamasyonda önemli olduğu düşünülmektedir (13). İn vivo ve in vitro çalışmalar, polifenollerin, TNF- $\alpha$, IL-1- $\beta$ ve IL-6'nın inhibisyonu gibi birçok inflamatuar yanıt regülatörünü inhibe ederek makrofajları etkilediğini göstermektedir (14).

Fenolik asitler sitokinlerin salgılanmasını etkileyerek önemli bir antiinflamatuar etki gösterirler. Çeşitli fenoliklerin, LPS ile aktive edilmiş fare primer makrofajları, aktif insan mast hücreleri, aktif insan astrositleri, insan sinoviyal hücreleri ve insan periferal kan mononükleer 
hücreleri gibi çoklu hücre tiplerindeki çeşitli proinflamatuar sitokinlerin ve kemokinlerin (TNF- $\alpha$, IL-1, IL-6, IL-8 ve monosit kemoatraktan protein-1 (MCP-1) ekspresyonunu inhibe edebildiği bulunmuştur (15-19).

Benzer şekilde; bitkilerden izole edilmiş polifenolik bileşiklerin (Apigenin ve Kuersetin) THP-1 makrofajlarında IL-6 ve TNF- $\alpha$ üretimini azaltarak antiinflamatuar aktivite gösterdiği bildirilmiştir (20). TNF- $\alpha$ seviyelerindeki azalma akut inflamatuar cevabı sınırlandırmaktadır (21, 22). IFN-y gibi diğer sitokinler de bazı polifenoller tarafından inhibe edilebilir. Örneğin, kaempferol, dalak hücrelerinde ve $T$ hücre hatlarında IFN-y üretimini doza bağlı azaltmaktadır (23). Bazı polifenoller, kuersetin ve kateşinler gibi pro- ve antiinflamatuar sitokinlerin üretimi arasındaki denge üzerinde etkilerini gösterir, TNF-alfa ve IL1 'i inhibe ederken IL-10 salımını arttırırlar. İnflamatuar sitokinlerin modülasyonu, genel olarak polifenollerin immünomodülatör etkilerini sergilediği yaygın mekanizmalardan biridir $(24,15)$. Bu çalışmada ise fenolik birleşiklerden biri olan FA'nın, LPS ile induklenmiş THP-1 hücrelerinde sitokin salınımına etkisine bakılarak antioksidan ve anti-inflamatuar etkisi araştırılmıştır.

\section{GEREÇ VE YÖNTEM}

\section{Kimyasallar}

$\mathrm{Bu}$ çalışmada; anti-inflamatuar aktivite belirlenmesi için makrofaj hücre kültürü "human monocytic cell line, THP-1" hücre hattı kullanıldı. McCoy's 5A, Fetal Bovine Serum, Penicilin/Streptomycin, L-Glutamin, TrypsinEDTA Capricorn Scientific'den. Ferulik asid ve Dimetil Sülfoksit (DMSO) Sigma'dan; WST-8 Cell Proliferation Assay Kit Cayman Chemical'dan temin edildi.

\section{Sitotoksisite ve Hücre Canlıığı Analizi}

\subsection{Hücre Canlılığı Analizi}

Hücre canlılık testi tripan mavisi kullanılarak yapıldı. Bu amaç ile hücreler $-80^{\circ} \mathrm{C}$ soğutucudan çıkartılıp hızla çözdürülerek, 2 mM L-glutamine, $\% 10$ fetal bovine serum ve \%2 penisilinstreptomisin ilaveli DMEM besi yerinde çoğaltıldı. Hücreler $37{ }^{\circ} \mathrm{C}$ ve $\% 5 \mathrm{CO}_{2}{ }^{\prime}$ li ortamda inkübe edilerek, düzenli aralıklarla pasajlandı. Hücrelerin canlııklarını ve sayılarını kontrol etmek için, Tripan mavisi boyası uygulandı. Bunun için, $50 \mu \mathrm{l}$ süspanse hücreye $50 \mu \mathrm{l}$ boya karıştırılıp, ışık mikroskobu ile hücrelerin canlılığına ve sayısına "Neubauer" lamı ile bakıldı. "Neubauer" lamındaki $4 \times 4$ ' lük karelerden oluşan dört adet alan sayıldı. Hücre zarı bütünlüğü bozulduğu için Tripan mavisi boyasını içine alan ve mavi renkte görünen hücreler ölü, hücre zarı yapısı bozulmayan hücreler ise boyayı içine almadığı için canlı olarak kabul edildi. Sayılan canlı hücrelerin toplamlarının ortalamasını alıp dilüsyon faktörü ve 20.000 ile çarpıp, ml'deki canlı hücre sayısı hesaplandı. Canlı hücre sayısının toplam hücre sayısına \% olarak oranlanmasıyla da hücre canlılığı hesaplandı.

\subsection{Sitotoksisite Analizi}

Etken maddenin her bir hücre kültürü üzerinde sitotoksisitesini saptamak için WST-8 (WST-8 Cell Proliferation Reagent,-Cayman) yöntemi kullanıldı. Hücreler 96-kuyucuklu plaklara başlangıç yoğunluğu 1 ml'de $3 \times 10^{6}$ olacak şekilde hesaplanıp her bir kuyucuğa $100 \mu \mathrm{l}$ dağıtılarak ve üzerine $100 \mu \mathrm{l}$ içerisinde belirli dozlarda $(100,250,350,500,650,800 \mu \mathrm{g} / \mathrm{ml})$ etken madde (Ferulik asit) içeren ortam eklenerek toplam $200 \mu$ l'ye tamamlandı.

Sitotoksisite analizi için deney 24,48 ve 72 . saat olmak üzere üç günlük kuruldu. Her üç günün inkübasyonundan sonra $10 \mu \mathrm{l}$ WST-8 (Water Soluble Tetrazolium Salt-8) solüsyonu eklenerek 4 saat sonunda mikro plaka okuyucuda (Multiskan FC, Thermo) $450 \mathrm{~nm}$ absorbans 620 $\mathrm{nm}$ referans aralığında okuma yapıldı

\subsection{LPS ile Indüklenen THP-1 Hücrelerinde}

\section{Sitokin Miktarlarının Belirlenmesi}

"İnsan monositik hücre hatt, THP-1", ISI ile inaktive edilmiş $\% 10$ fetal bovin serum, $100 \mathrm{U} / \mathrm{mL}$ penisilin ve $100 \mu \mathrm{g} / \mathrm{mL}$ streptomisin eklenen Roswell Park Memorial Institute-1640 (RPMI1640) ortamında, $37{ }^{\circ} \mathrm{C}$ 'de $\% 5 \quad \mathrm{CO}_{2}$ ile nemlendirilmiş inkübatörde kültürlendi.

"İnsan monositik hücre hattı, THP-1", hücreleri, inflamasyonu uyarmak için kullanılması gereken LPS konsantrasyonu belirlenmesi çalışmaları yapıldı. Literatürde, LPS ile THP-1 hücrelerinin aktivasyonuna yönelik yürütülen çalışmalarda farklı konsantrasyonlarda ve sürelerde uygulamalar yapılarak TNF alfa düzeyleri ölçülmüş ve en uygun konsantrasyon ve süre belirlenmiştir (Tablo-1).

$\mathrm{Bu}$ çalışmada uygun konsantrasyon ve süreyi belirleyebilmek için 0-2 mikrogram $/ \mathrm{mL}$ aralığında $(0.1, \quad 0.5, \quad 2$ ve 2 mikrogram $/ \mathrm{mL}$ konsantrasyonlarda) LPS, THP-1 hücrelerine ekleyerek 1-24 saat aralığında farklı zamanlarda $(1,2,3,4,6,18$ ve 24 saat) TNF alfa ölçümü yapıldı (Şekil-1). 


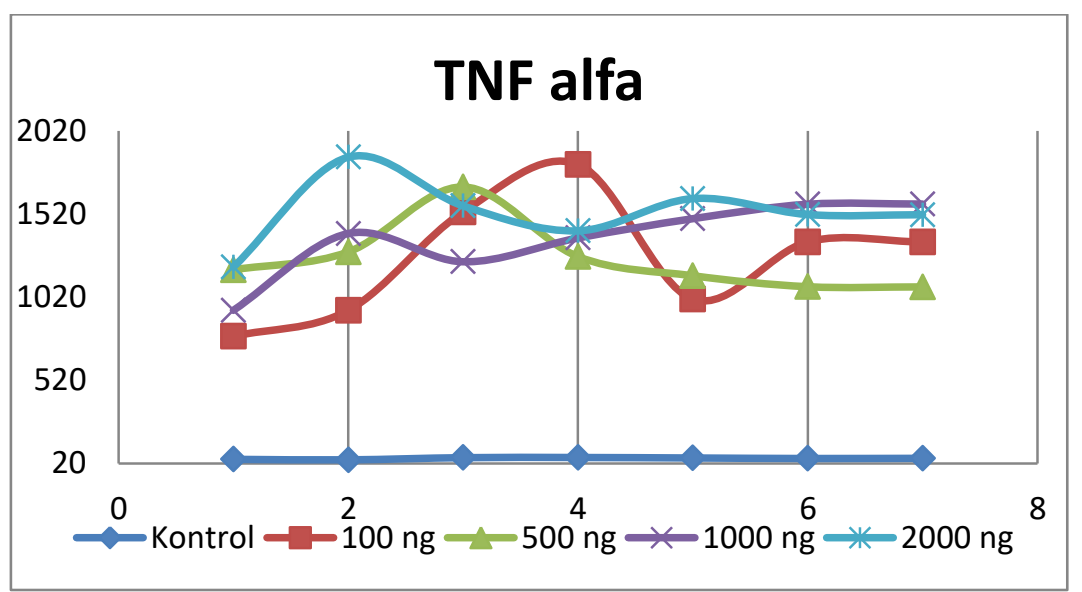

Şekil-1. Farklı konsantrasyonlarda ve sürede (1, 2, 3, 4, 6, 18, 24 saat)

LPS uygulaması ile TNF alfa düzeyindeki değişimler.

Tablo-1. Yapılan literatür taramasında kullanılan LPS konsantrasyonları.

\begin{tabular}{llll}
\hline $\begin{array}{l}\text { Hücre } \\
\text { hattı }\end{array}$ & $\begin{array}{l}\text { LPS } \\
\text { konsantrasyonu }\end{array}$ & $\begin{array}{l}\text { Süre } \\
\text { (saat) }\end{array}$ & Kaynak \\
\hline RAW & $1000 \mathrm{ng} / \mathrm{mL}$ & 22 & $(166)$ \\
264 & $100 \mathrm{ng} / \mathrm{mL}$ & 6 & $(167)$ \\
THP-1 & $100 \mathrm{ng} / \mathrm{mL}$ & 24 & $(168)$ \\
THP-1 & $200 \mathrm{ng} / \mathrm{mL}$ & 24 & $(169)$ \\
THP-1 & $1000 \mathrm{ng} / \mathrm{mL}$ & 4 & $(170)$ \\
THP-1 & $1000 \mathrm{ng} / \mathrm{mL}$ & 48 & $(171)$ \\
THP-1 & $10000 \mathrm{ng} / \mathrm{mL}$ & 4 & $(172)$ \\
THP-1 & & & \\
\hline
\end{tabular}

$100 \mathrm{ng} / \mathrm{mL}$ konsantrasyonda en yüksek TNF alfa düzeyi 4. saatte elde edilirken, 500 ve 1000 $\mathrm{ng} / \mathrm{mL}$ LPS ile en yüksek TNF alfa düzeyi 3 . Saatte ve $2000 \mathrm{ng} / \mathrm{mL}$ konsantrasyonda ise en yüksek TNF alfa düzeyi 2 . saatte elde edildi. $2000 \mathrm{ng} / \mathrm{mL}$ konsantrasyonunda elde edilen TNF alfa yüksekliği daha sürekli olduğu için çalışmamızda $2000 \mathrm{ng} / \mathrm{mL}$ konsantrasyon ve 2 saatlik süre enflamasyon oluşumunu uyarmak için seçildi.

Normal ve aktive olmuş THP-1 hücreleri 1 saat süresince önceden belirlenmiş konsantrasyonda ferulik asit ile muamele edildi. LPS $(2000 \mathrm{ng} / \mathrm{mL})$ içeren, ferulik asit içermeyen kuyucuk ferulik asit etkisini karşılaştırmak için kullanıldı. Ayrıca hiçbir şey içermeyen kuyucuk kontrol olarak kabul edildi

\subsubsection{Sitokin Analizi}

LPS ile uyarılmış ve uyarılmamış "Human monocytic cell line, THP-1", hücreleri $\left(1 \times 10^{6} / \mathrm{mL}\right)$ ferulik asit ile 1 saat süresince inkübe edildikten sonra alınan örneklerde analizler gerçekleştirildi.
LPS (2000 $\mathrm{ng} / \mathrm{mL})$ içeren, ferulik asit içermeyen kuyucuk ferulik asidin etkisini karşılaştırmak için kullanıldı. Ayrıca hiçbir şey içermeyen kuyucuk kontrol olarak kabul edildi. Hücre kültüründe ferulik asit ile muamele sonucunda açığa çıkan inflamatuar sitokinlerin (Siklooksijenaz-1 (COX), IL-1 $\alpha$, IL-1 $\beta$, NF-k $\beta$, IL-6, IL-10, TNF- $\alpha$ ve IFN- $\gamma$ ) düzeylerindeki değişimler hücre kültürü süpernatantında ELISA kiti kullanılarak belirlendi.

Sitokin analizlerinde kullanılan LPS, FA ve mersin bitkisi dozları;

- LPS ile uyarılmış hücre hattı (LPS dozu: 2000 $\mathrm{ng} / \mathrm{mL}$ )

- Ferulik asit (Ferulik asit konsantrasyonu: 500 $\mu \mathrm{g} / \mathrm{mL}$ )

\section{4 İstatistik}

Hücre kültüründe elde edilen absorbans değerleri $\%$ canlılık ve \% sitotoksisiteye çevrilmiş, grafikleri Graphpad v5 programında çizilmiştir. Verilerin analizinde iki-yönlü ANOVA testi ve post test olarak Bonferroni testi kullanılmıştır. $I_{50}$ değerleri ise CalcuSyn (Biosoft) yazılımı kullanılarak hesaplanmıştır.

\section{BULGULAR}

\section{Hücre Kültüründe Gerçekleştirilen Analiz Sonuçları}

\subsection{Sitotoksisite ve Hücre Canılıı̆ı Analiz Sonuçları (Toksik doz belirlenmesi)}

Ferulik asidin THP-1 akut monositik lösemi hücre hattındaki 100, 250, 350, 500, 650, $800 \mu \mathrm{g} / \mathrm{ml}$ konsantrasyonlarının sitotoksik etkileri Şekil-2,-3 ve -4 de sunulmuştur. 


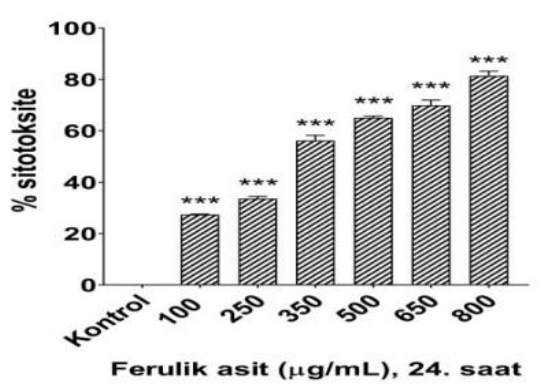

Şekil-2. Ferulik asidin THP-1 hücre hattı üzerinde 24, saat sitotoksik etki değerleri ${ }^{* * *}: p \leq 0,001$

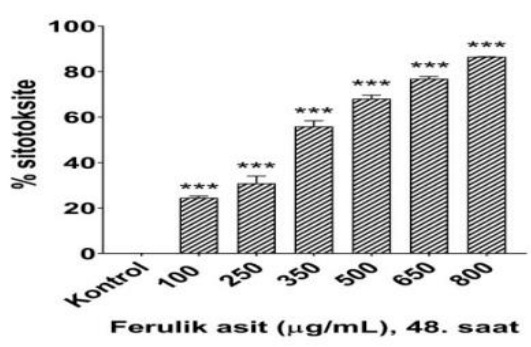

Şekil-3. Ferulik asidin THP-1 hücre hattı üzerinde 48, saat sitotoksik etki değerleri ${ }^{* * *}: p \leq 0,001$

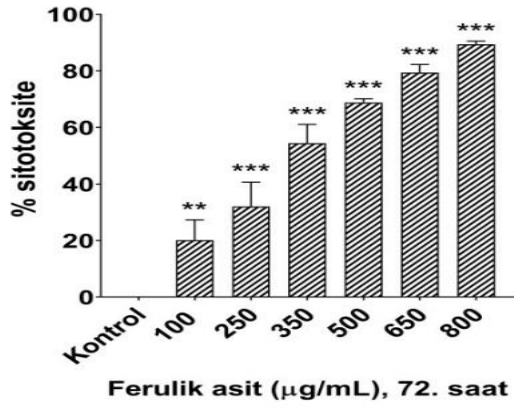

Şekil-4. Ferulik asidin THP-1 hücre hattı üzerinde 72 saat sitotoksik etki değerleri ${ }^{* *}: \mathbf{p} \leq \mathbf{0 , 0 1},{ }^{* * *}$ : $\mathrm{p} \leq \mathbf{0 , 0 0 1}$

THP-1 hücre hattı üzerinde ferulik asidin 24, 48 ve 72. saatlerdeki IC50 değerleri sırasıyla 291,6; 284,$1 ; 287,4 \mu \mathrm{g} / \mathrm{ml}$ olarak hesaplanmıştır.

\subsection{Hücre Kültüründe Sitokin Sonuçları}

Hücre kültüründe sitokin analizi sonuçları Şekil-5, $6,7,8,9,10,11$ ve 12 de sunulmuştur.

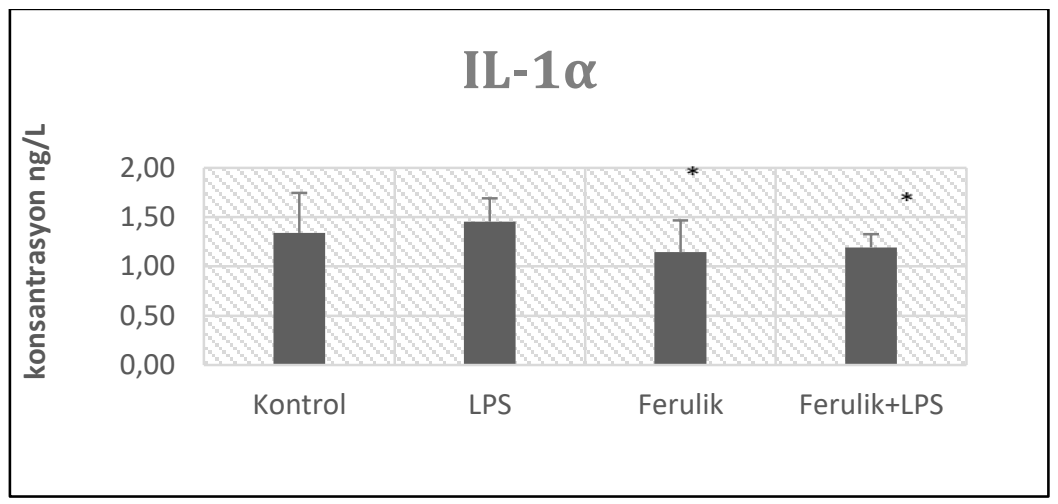

Şekil-5. IL-1a (ng/l) sonuçları.

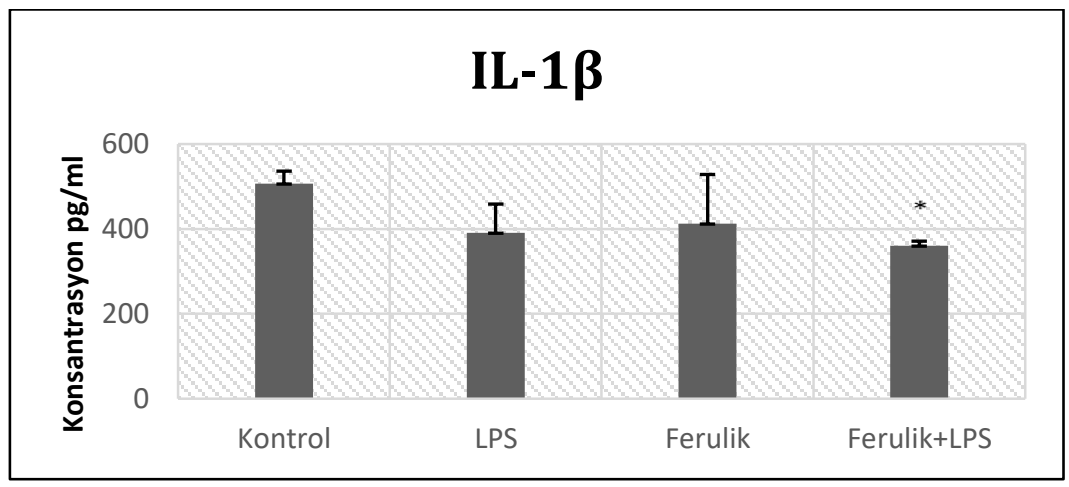

Şekil-6. IL-1ß (pg/ml) sonuçları. 


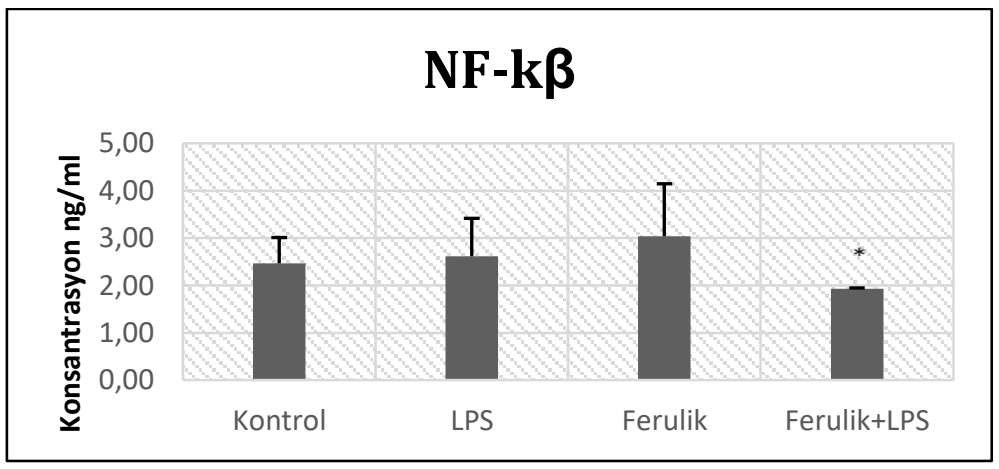

Şekil-7. NFKB (ng/ml) sonuçları.

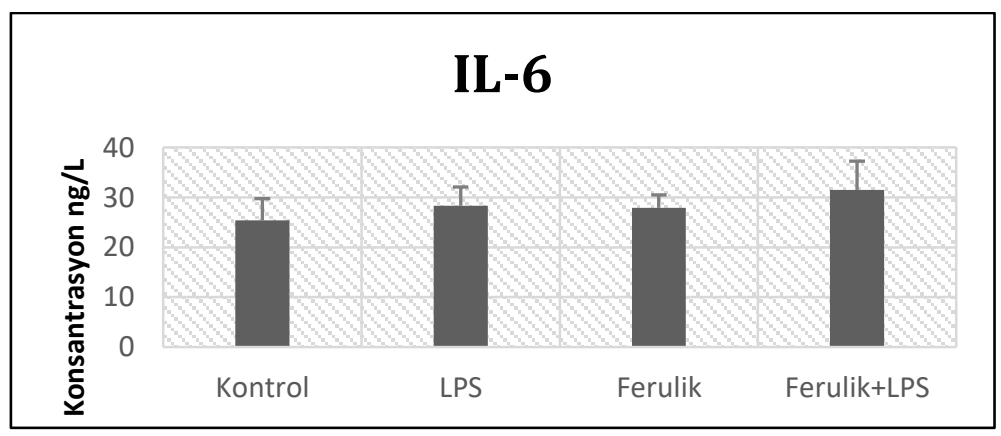

Şekil-8. IL-6 (ng/ml) sonuçları.

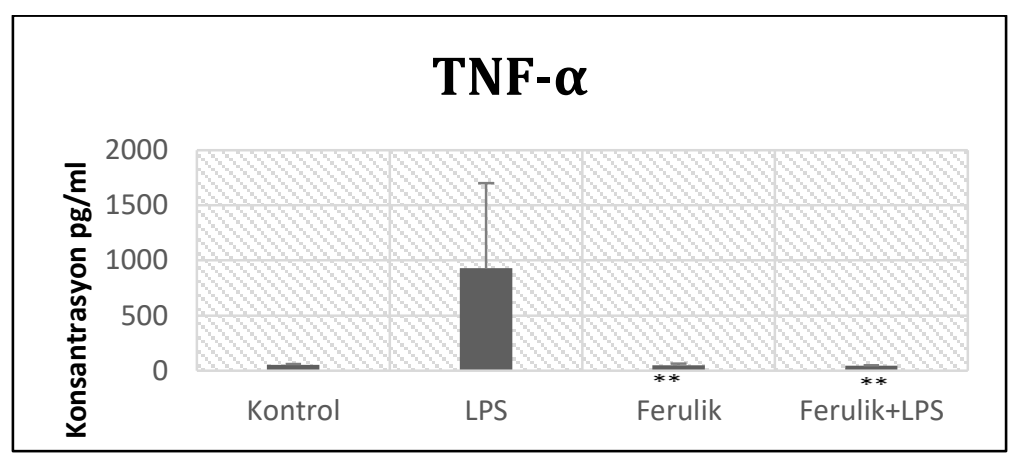

Şekil-9. TNF- $\alpha$ (pg/ml) sonuçları.

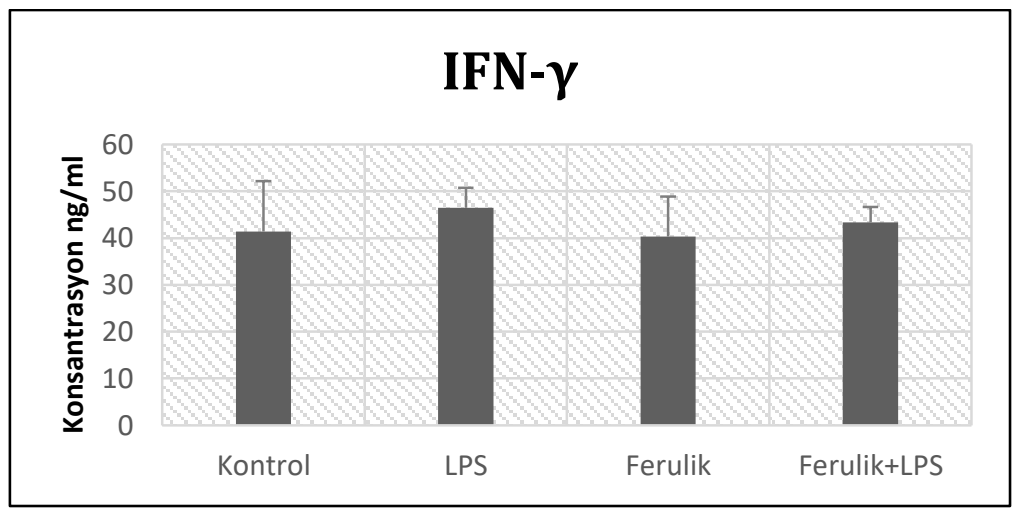

Şekil-10. IFN-ץ (ng/ml) sonuçları. 


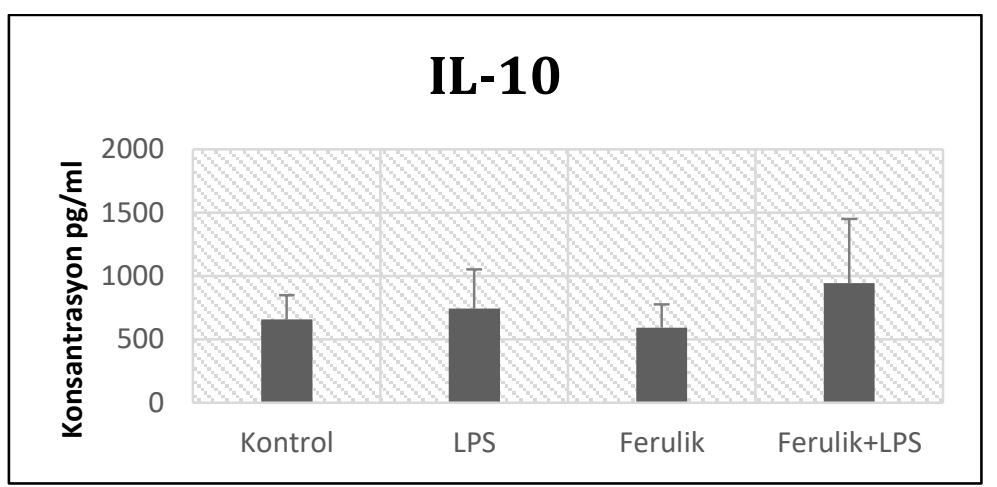

Şekil-11. IL-10 (pg/ml) sonuçları.

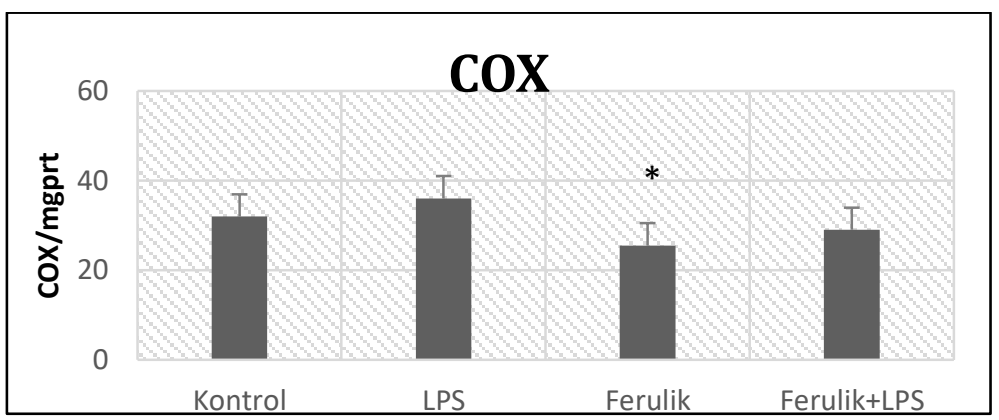

Şekil-12. COX-1 sonuçları.

LPS ile uyarılan hücrelerin IL-1a seviyelerinde Kontrol ve diğer gruplara göre artış gösterdiği görüldü $\left({ }^{*} ; p \leq 0,05\right)$. Diğer örneklerde IL-1 $\alpha$ seviyesi Kontrole göre düşüş gösterdi ancak istatistiksel olarak anlamlı bulunmadı.

IL-1 $\beta$ sonuçları incelendiğinde; LPS+FA, IL-1 $\beta$ seviyelerinin kontrole göre düşüş gösterdiği görüldü ve istatistiksel olarak anlamlı fark (LSD testi) bulundu ( $\left.{ }^{*} ; p \leq 0,05\right)$.

LPS ile uyarılan hücrelerin NFk- $\beta$ seviyelerinin Kontrole göre artış gösterdiği fakat istatistiksel olarak anlamlı olmadığı görüldü. Diğer örneklerde NFk- $\beta$ seviyeleri Kontrol ve LPS grubuna göre düşüş gösterdi ve FA+LPS örneği istatistiksel olarak anlamlı düşük bulundu ( $\left.{ }^{*} ; p \leq 0,05\right)$.

LPS grubu IL- 6 seviyeleri Kontrol grubuna göre artış gösterse de istatistiksel olarak anlamlı fark bulunmadı. Ferulik asit IL-6 seviyesi, LPS grubuna göre düşüş gösterse de istatistiksel olarak anlamlı fark bulunmadı.

LPS grubunun TNF- $\alpha$ seviyesinin Kontrol grubu ve diğer gruplara göre önemli bir artış gösterdiği görüldü ve LPS ile diğer bütün gruplar arasında istatistiksel olarak anlamlı fark bulundu ( $p \leq 0,01)$. Ferulik asit, FA+LPS, TNF- $\alpha$ seviyeleri Kontrol grubuna göre düşüş gösterdi ve istatistiksel olarak anlamlı fark bulundu.
LPS grubunun IFN-y seviyelerinde Kontrol grubuna ve diğer gruplara göre artış gösterdiği görüldü. Ferulik asit eklenmesi IFN-ץ seviyelerini etkilemedi.

LPS grubunun IL-10 seviyelerinde Kontrol grubuna göre hafif bir artış görülse de istatistiksel olarak anlamlı değildi.

COX-1 sonuçları incelendiğinde; LPS grubunun Siklooksijenaz seviyesinin Kontrol grubu ve diğer gruplara göre anlamlı artış gösterdiği görüldü ve LPS ile ferulik asit arasında istatistiksel olarak anlamlı fark bulundu $\left({ }^{*}, p \leq 0,05\right)$. Ferulik asit, FA+LPS, COX-1 seviyeleri Kontrol grubuna göre düşüş gösterdi ve istatistiksel olarak anlamlı bir fark gözlenmiştir.

\section{TARTIŞMA}

LPS güçlü bir inflamasyon indükleyicisidir ve hücrelerin LPS ile indüklenmesi inflamasyonu yaygın şekilde artırabilir. LPS, TNF- $\alpha$, IL-1 $\alpha$, IL$1 \beta$ ve IL-6'yı içeren pro-inflamatuar sitokinlerin seviyelerini arttırır. İnterleukinler ilk olarak, lektinlere karşı $T$ hücre yanıtını arttıran lipopolisakarit (LPS) ile inkübe edilmiş lökositler tarafından üretilen pirojenik moleküller olarak tanımlanmıştır $(25,26)$. Bu çalışmada LPS ile indükleme ile oluşturulan inflamatuar yanıtta 
FA'nın inflamatuar sitokinler üzerindeki etkisi araştırılmış ve ferulik asidin bazı inflamatuar molekülleri baskılayarak anti inflamatuar etki gösterdiği ortaya konmuştur.

Çalışmada kullanılan FA (4-hidroksi-3-metoksi sinamik asit), kimyasal yapısında fenolik gruba sahip doğal bir bileşiktir. Antioksidan özelliklerine ek olarak, yapılan araştırmalar FA'nın aynı zamanda antikanserojen (27), antiinflamatuar, anti-mutajenik (28) etkilere sahip olduğunu göstermiştir. Ferulik asit, hidroksi, süperoksit radikalleri, NO ve peroksinitriti temizleyerek antioksidan aktivitesini göstermektedir (29). Bizim çalışmamızda THP-1 hücrelerine ve LPS ile indüklenen hücrelere FA eklenmesi IL-1 alfa, IL1beta, TNF alfa, ve siklooksijenaz düzeylerini düşürmüştür. Ferulik asit IFN gama, NFkappa- $\beta$, IL-6 düzeylerinde anlamlı bir değişikliğe neden olmamış, ancak LPS ile indüklenen hücrelerde FA eklenmesi NFkappa- $\beta$ düzeyini düşürmüştür. İlginç olarak LPS ile indüklenen hücrelerde FA eklenmesi IL-10 düzeylerinde artışa yol açmıştır.

İflamatuar yanıtta makrofajlar, pro-inflamatuar sitokinlerin üretimi yoluyla önemli bir rol oynar. TNF- $\alpha$ 'daki artış pro-inflamatuar sitokin sekresyonunu arttırır ve adiponektin gibi antiinflamatuar sitokinleri azaltır (30, 31). Çalışma sonuçlarımıza benzer şekilde, Gerin ve ark. yapmış oldukları çalışmada FA'nın formaldehit kaynaklı hepatotoksisite üzerindeki koruyucu etkilerini incelemek amacıyla doku süperoksit dismutaz (SOD), katalaz (CAT), glutatyon peroksidaz (GSH-Px) aktiviteleri, doku malondialdehit (MDA) seviyeleri ve serum TNF- $\alpha$, IL-6, IL-1, IL-8, toplam protein, seviyelerini ölçmüşlerdir. Ferulik asit tedavisinin MDA ve sitokin düzeylerini (IL-6, TNF- $\alpha$, IL-1, IL-8) düşürdüğünü ve özellikle IL-1 konsantrasyonlarını düşürdüğünü belirtmişlerdir (32). Szulc-Kielbik ve ark. alfa lipoik asitin (ALA), ferulik asit'in serbest radikal temizleme kapasitesi ve anti-inflamatuar aktivitelerini incelemişlerdir. Hem ALA hem de FA'nın, inflamatuar makrofajların varlığında reaktif oksijen türlerinin (ROS) oluşumunu sınırladığını ve FA'nın, proinflamatuar IL-1 $\beta$ ve IL-6'nın lipopolisakarit ile aktive edilen makrofajlarla salımını azaltığını bildirmişlerdir (33). Zhang ve ark. FA'nın akut solunum sıkıntısı sendromu (ARDS), profilaksisinde faydalı olup olmadığını araştırmak amacı ile LPS uygulamasını kullanarak bir ARDS sıçan modeli oluşturmuşlardır. FA tedavisinin, LPS kaynaklı akciğer BALF'de IL-1 $\beta$, IL-6, TNF$\alpha$ 'yı baskıladığını ve IL-10 salgılanmasını arttırdığı ve böylece bir anti-inflamatuar etki gösterdiğini bildirmişlerdir. Ferulik asidin malondialdehit ve myeloperoksidaz seviyelerini baskıladığı ve toplam antioksidan kapasitesini yükselttiği bildirilmiştir (34).

Hem IL-1 alfa hem de IL-1 $\beta$, IL-1R üzerinden sinyal verir. Pro IL-1 $\beta$ 'in kaspaz-1 ile bölünmesi biyoaktif IL-1 $\beta$ üretmek için gerekliyken, hem proIL-1 $\alpha$ hem de olgun IL-1 $\alpha$ benzer kinetiklerle IL$1 R$ 'ye bağlanmakta olup, epitelyal ve hematopoetik sistem üzerinde IL-6 ve TNF'nin salgılanmasına neden olabilirler $(35,36)$. IL-1a ve IL-1 $\beta$, farklı kanser türlerinde benzer veya zIt fonksiyonlara sahip olabilir. Hem IL-la hem de IL$1 \beta^{\prime}$ nin ekspresyonu genotoksik stres sırasında artar ve nekroz veya piroptozla salgılanması, tümör dokusunda vasküler endotel büyüme faktörü (VEGF) ekspresyonunu teşvik eder (37). Yaptığımız çalışmada, LPS ile uyarılan hücrelerde IL-1 $\alpha$ ve IL-1 $\beta$ seviyesinin yükseldiği, bunun yanı sıra FA ve FA+LPS'nin IL-1 $\alpha$ ve IL-1 $\beta$ seviyesini düşürdüğü gözlendi. IL-1 $\alpha$ ve IL-1 $\beta$ seviyesindeki düşme, inflamasyonun önlenmesi anlamına geldiği için, bu sonuçlar kronik inflamasyonun patogenezinde rol aldığı pek çok oto-immun ve neoplastik hastalığın önlenmesinde katkısının olabileceğini düşündürmektedir.

Nükleer faktör kappa $\beta$ (NFk- $\beta$ ) inflamatuar yanıtın merkezinde yer alan, dimerik transkripsiyon faktörleri ailesinin bir üyesi olan, doğal ve kazanılmış immunitede, hücresel farklılaşma ve çoğalmada etkili bir sitokindir. NFk$\beta$ sistemi sıkıca denetim altında olup, NFk- $\beta$ 'nın yanlış düzenlemesi sonucu kanser ve bağışıklık sistemi bozukluklarına neden olabilen durumlar meydana gelebilmektedir $(38,39)$. Bizim çalışmamızda ise LPS ile uyarılan hücrelerde ve FA verilen hücrelerde NFk- $\beta$ seviyelerinin hafif arttığı tespit edildi. FA+LPS'nin NFk- $\beta$ seviyelerini Kontrol ve LPS grubuna göre düşürdüğü gözlendi. Bizim sonuçlarımıza benzer olarak, Kim ve ark. FA'nın (50 $\mu \mathrm{M}, 30 \mathrm{dk}$ inkübasyon), NFk$\beta$ 'nin inhibisyonu yoluyla LPS (50 ng/ml, 24 saat inkübasyon) ile uyarılan RAW 264.7 makrofajlarında iNOS ekspresyonunu inhibe ettiğini gösterdi (40). Ayrıca, bir FA türevi, FA etil esterin, LPS ile uyarılan RAW 264.7 makrofajlarında NFk- $\beta$ 'nin translokasyonunu inhibe ettiği de bildirilmiştir (41).

Çalışmamızda, LPS verilen hücrelerde siklooksijenaz seviyesinin Kontrol grubu ve diğer gruplara göre anlamlı bir artış gösterdiği, FA ise siklooksijenazı LPS grubuna ve kontrole göre düşürdüğü görüldü. Literatürde FA'nın COX-2 
ekspresyonuna etkisi ile ilgili farklı sonuçlar bulunmaktadır. Nagasaka ve ark., Sikloartenil ferülatın $(1 \mu \mathrm{M}, 22$ saat inkübasyon, $1 \mathrm{ug} / \mathrm{ml}$ LPS ile 2 saat inkübasyon), NFk- $\beta$ 'nin inhibisyonu ile iNOS ve COX-2 ekspresyonunu inhibe ettiğini bulmuşlardır (42). Hirata ve ark. ferulik asit türevlerinin $(10 \mu \mathrm{M}, 30 \mathrm{dk}$ inkübasyon) LPS (100 $\mathrm{ng} / \mathrm{ml}, 3$ saat inkübasyon) ile uyarılmış RAW 264.7 makrofajlarında COX-2 ekspresyonu üzerinde inhibe edici etkiye sahip olduğunu, ancak FA'nın böyle bir etkisi olmadığını göstermiştir (43). Bizim çalışmamız da farklı bir hücrede (THP-1) FA COX-1 düzeylerini düşürmüştür, bu düşme NFk- $\beta$ ile birlikte olduğu için bu yol aracılığı ile olduğu düşünülmüştür.

Yapmış olduğumuz çalışmada incelemiş olduğumuz bir diğer sitokin olan TNF- $\alpha$, hücreler arası bir iletişim molekülüdür. TNF-a'nın merkezi rolü, muhtemelen doğal immün sistemde inflamatuar reaksiyonların başlatılmasıdır. Bakteriyel patojenler ve diğer birçok zararlı uyarıcılar, Toll benzeri reseptörler ve NFk- $\beta$ yoluyla TNF- $\alpha^{\prime} y ı$ indükler ve çevrimsel etkinliğini arttırır. Hasar ve enfeksiyon bölgelerinde TNFa'nın erken üretimi; kemokinleri, sitokinleri, endotelial adezyon moleküllerini, nötrofilleri, makrofajları ve lenfositleri içeren oldukça karmaşık bir biyolojik yolağı aktive eder (44). NFk- $\beta^{\prime} y i$ aktive edecek pozitif bir otokrin geribildirimin (Feedback) neden olduğu TNF- $\alpha$ ile GM-CSF ve IL-8 gibi sitokinlerle de indüklenir $(44,45)$. TNF-a'nın doğru yerde ve doğru zamanda üretilmesi, etkili ve kontrollü bir inflamatuar yanıt için oldukça önemlidir. $\mathrm{Bu}$ sitokin, birçok farklı hücre tipi tarafından üretilir ve sitokinin Tip I reseptörü vücutta pek çok yerde bulunur. TNF üretiminin kısıtlanması, yararlı fonksiyonlarının kontrol edilir olmasını sağlayan mekanizmalardan biri olabilir. LPS'ye yanıt olarak üretilen TNF- $\alpha$, esas olarak monosit ve nötrofil hücreleri tarafından üretilir. $\mathrm{T}$-hücre kaynaklı üretilen TNF- $\alpha$, vücuttaki yüksek bakteri yüküne karşı koruma için önemli iken, mast hücre kaynaklı TNF- $\alpha$ ise alerjik cevabın kritik ve erken bir bileşenidir (46). TNF- $\alpha$ hücrenin konak savunmasında, hücreler arası iletişimde, inflamatuar süreçte ve organogenezde kritik rol almaktadır. Inflamatuvar ve otoimmün hastalıklarda yapılan çeşitli hayvan deneylerinde, lokal veya sistemik TNF- $\alpha$ üretiminin kollajen kaynaklı artrit, otoimmün hepatit, idiyopatik pnömoni sendromu ve bleomisin kaynaklı akciğer fibrozu durumlarında arttığı saptanmıştır $(47,48)$. Yapmış olduğumuz bu çalışmada LPS ile uyarılan hücrelerde TNF- $\alpha$ seviyesi, kontrol grubu ve diğer gruplara göre istatistiksel olarak anlamlı artış gösterirken, FA TNF- $\alpha$ düzeyini düşürerek anti-inflamatuar etki gösterdiği görüldü.

Interferon gama (IFN- $\gamma$ ) aktive CD4+ veya CD8+ $T$ hücreleri ve doğal öldürücü hücreler tarafından üretilen bir sitokin olup, adaptif bağışıklıkta oldukça önemlidir (49). IFN gama'nın biyolojik aktiviteleri arasında yer alan makrofaj aktivasyonu, kilit öneme sahiptir. Buna göre, IFN gama çeşitli pro-inflamatuar parametrelerin (TNF$\alpha$, interferon ile indüklenebilir protein-10, iNOS, kaspaz-1) yeniden düzenlemesini sağlamaktadır (50-53). Bunun dışında, IFN-y'nın aynı zamanda proinflamatuar transkripsiyon faktörü nükleer faktör B'nin (NFk- $\beta$ ) de aktivasyonuna katkısı bulunmaktadır (54). İnterferon gama'ya bağı hiperaktive olmuş lökositlerin apopitozunun indüksiyonu iltihabı sınırlamaktadır. Yaptığımız çalışmada, LPS ile uyarılan hücrelerde IFN-Y seviyeleri kontrol grubuna ve diğer gruplara göre hafif bir artış gösterdi. Ferulik asit ve FA+LPS, IFN Y seviyelerinde düşüşe neden olsa da bu sonuçlar istatistiksel olarak anlamlı değildi. IFNgama (Tip II IFN) başlıca T lenfositler ve doğal öldürücü hücreler (Natural killer) tarafından üretildiği için bakteriyel bir polisakkarit olan LPS'ye yanıt olarak değişiklik göstermemesi beklenen bir sonuçtur (55).

İnterlökin-10 (IL-10) 1990 yılında izole edilmiş, makrofajlar ve T hücre alt kümelerini içeren çeşitli hücre tipleri tarafından salgılanmakta olan pleotropik bir sitokindir (56). Anti-inflamatuar sitokin IL-10, STAT3 aktivasyonu gerektiren bir işlem olan çoklu, inflamatuar mediatörlerin aktive edilmiş makrofajlardan ve dendritik hücrelerden üretilmesini önler. LPS ile uyarılan hücrelerde IL10 seviyelerinde, kontrol grubuna göre artış olduğu görüldü. Ferulik asitin IL-10 seviyesinde azalma gösterdiği görülse de bu gruplar arasında istatistiksel olarak anlamlı fark bulunmadı. Çalışmamızda LPS'le indüklenen hücrelerde ferulik asit eklenmesi ile IL-10 düzeyleri artmıştır. Anti inflamatuar etkinliği açısında IL-10'a ait iki yönlü etkinin olması nedeniyle, net bir yorum yapmak için daha ileri çalışmalara intiyaç duyulmaktadır.

\section{SONUÇ}

Bizim yapmış olduğumuz çalışmada FA'nın IL$1 \beta$, IL-1 $\alpha$, TNF- $\alpha$ ve NF-k $\beta$ sitokin düzeyi sonuçları literatürde yapılan yukardaki çalışmalar ile uyum içinde olup, çalışmamızda elde etmiş olduğumuz sonuçları destekler niteliktedir. Ferulik 
asidin, reaktif oksijen türlerini (ROS) zararsız hale getirerek proinflamatuar sitokin üretimini azaltarak özellikle bakteriyel ajanlarla uyarılan inflamasyonda anti-inflamatuar etki gösterebileceği ortaya konmuştur. Çalışmamızın sonuçları, bazı bitkisel ürünlerde yüksek oranda bulunabilen FA'nın anti-inflamatuar etkisini göstermiş olup doğal ürünlerin anti-inflamatuar amaçlarla kullanımı için yapılacak olan ileriki çalışmalara ışık tutacaktır.

\section{Teşekkür}

Bu çalışma Ege Üniversitesi Bilimsel Araştırma Projeleri Kordinatörlüğü tarafından desteklenmiştir (Proje 16-TIP-049), bu projedeki destekleri için teşekkür ederiz. Yazarlar, teknik yardımlarından dolayı Ege Üniversitesi Çocuk Hastanesi Metabolizma Laboratuvarına çok teşekkür eder.

\section{Çıkar çatışması}

Çalışmada adı geçen yazarların mali veya başka türlü çıkar çatışması yoktur. Tüm yazarlar sunulan çalışmayla ilgisi olabilecek herhangi bir kuruluştan mali veya başka türlü hiçbir destek alınmadığını, çalışmayı etkilemiş gibi görünebilecek başka ilişki veya faaliyetlerin olmadığını beyan ederler.

\section{Kaynaklar}

1. D'Archivio, M., Filesi, C., Di Benedetto, R., Gargiulo, R., Giovannini, C. and Masella, R. (2007). Polyphenols, dietary sources and bioavailability. Annali dell'Istituto Superiore di Sanita, 43 (4), 348-361.

2. Rondini L., Peyrat-Maillard M.-N., Marsset-Baglieri A., and Berset C., (2002). Sulfated ferulic acid is the main in vivo metabolite found after short-term ingestion of free ferulic acid in rats. Journal of Agricultural and Food Chemistry, 50 (10), 3037-3041.

3. Mancuso, C., \& Santangelo, R. (2014). Ferulic acid: pharmacological and toxicological aspects. Food and Chemical Toxicology, 65, 185-195.

4. Kundu, J. K., \& Surh, Y. J. (2008). Inflammation: gearing the journey to cancer. Mutation Research/Reviews in Mutation Research, 659 (1-2), 15-30.

5. Larsen, G. L., \& Henson, P. M. (1983). Mediators of inflammation. Annual review of immunology, 1 (1), $335-359$.

6. Erwig, L. P., \& Rees, A. J. (1999). Macrophage activation and programming and its role for macrophage function in glomerular inflammation. Kidney and Blood Pressure Research, 22 (1-2), 21-25.

7. Lawrence, T., Willoughby, D. A., \& Gilroy, D. W. (2002). Anti-inflammatory lipid mediators and insights into the resolution of inflammation. Nature Reviews Immunology, 2 (10), 787-795.

8. Kobayashi, S. D., Voyich, J. M. Burlak, C., \& DeLeo, F. R. (2005). Neutrophils in the innate immune response. Archıvum Immunologıae Et Therapıae Experımentalıs-Englısh Edıtıon, 53 (6), 505.

9. Italiani, P., \& Boraschi, D. (2014). From monocytes to M1/M2 macrophages: phenotypical vs. functional differentiation. Frontiers in immunology, 5, 514.

10. Wang, J. Q., Jeelall, Y. S., Ferguson, L. L., \& Horikawa, K. (2014). Toll-like receptors and cancer: MYD88 mutation and inflammation. Frontiers in immunology, 5, 367.

11. Lu, Y. C., Yeh, W. C., \& Ohashi, P. S. (2008). LPS/TLR4 signal transduction pathway. Cytokine, 42 (2), $145-151$.

12. Boshtam M., Asgary S., Kouhpayeh, S., Shariati, L., \& Khanahmad, H. (2017). Aptamers against pro-and antiinflammatory cytokines: a review. Inflammation, 40 (1), 340-349.

13. González R., Ballester I., López-Posadas, R., Suárez, M. D., Zarzuelo, A., Martinez-Augustin, O.et al. (2011). Effects of flavonoids and other polyphenols on inflammation. Critical reviews in food science and nutrition, 51 (4), 331-362.

14. Comalada, M., Ballester, I., Bailon, E., Sierra, S., Xaus, J., Gálvez, J. et al. (2006). Inhibition of proinflammatory markers in primary bone marrow-derived mouse macrophages by naturally occurring flavonoids: analysis of the structure-activity relationship. Biochemical pharmacology, 72 (8), 1010-1021.

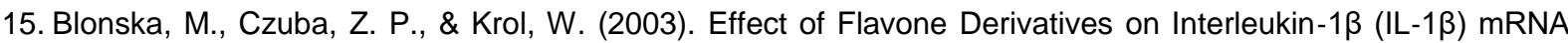
Expression and IL-1 $\beta$ Protein Synthesis in Stimulated RAW 264.7 Macrophages. Scandinavian Journal of Immunology, 57 (2), 162-166.

16. Sharma, V., Mishra, M., Ghosh, S., Tewari, R., Basu, A., Seth, P.,et al. (2007). Modulation of interleukin-1 $\beta$ mediated inflammatory response in human astrocytes by flavonoids: implications in neuroprotection. Brain research bulletin, $73(1-3), 55-63$. 
17. Min, Y. D., Choi, C. H., Bark, H., Son, H. Y., Park, H. H., Lee, S., et al. (2007). Quercetin inhibits expression of inflammatory cytokines through attenuation of NF-KB and p38 MAPK in HMC-1 human mast cell line. Inflammation Research, 56 (5), 210-215.

18. Lyu, S. Y., \& Park, W. B. (2005). Production of cytokine and NO by RAW 264.7 macrophages and PBMC in vitro incubation with flavonoids. Archives of pharmacal research, 28 (5), 573.

19. Drummond, E. M., Harbourne, N., Marete, E., Martyn, D., Jacquier, J. C., O'Riordan, D.,et al. (2013). Inhibition of proinflammatory biomarkers in THP1 macrophages by polyphenols derived from chamomile, meadowsweet and willow bark. Phytotherapy Research, 27 (4), 588-594.

20. Schindler, R., Mancilla, J., Endres, S., Ghorbani, R., Clark, S. C., \& Dinarello, C. A. (1990). Correlations and interactions in the production of interleukin-6 (IL-6), IL-1, and tumor necrosis factor (TNF) in human blood mononuclear cells: IL-6 suppresses IL-1 and TNF. Blood, 75, 40-47

21. Essafi-Benkhadir, K., Refai, A., Riahi, I., Fattouch, S., Karoui, H., \& Essafi, M. (2012). Quince (Cydonia oblonga Miller) peel polyphenols modulate LPS-induced inflammation in human THP-1-derived macrophages through NF-kB, p38MAPK and Akt inhibition. Biochemical and Biophysical Research Communications, 418 (1), 180-185.

22. Okamoto, I., Iwaki, K., Koya-Miyata, S., Tanimoto, T., Kohno, K., Ikeda, M., \& Kurimoto, M. (2002). The flavonoid Kaempferol suppresses the graft-versus-host reaction by inhibiting type 1 cytokine production and CD8+ T cell engraftment. Clinical immunology, 103 (2), 132-144.

23. Yahfoufi, N., Alsadi, N., Jambi, M., \& Matar, C. (2018). The immunomodulatory and anti-inflammatory role of polyphenols. Nutrients, 10 (11), 1618.

24. Beeson, P. B. (1948). Temperature-elevating effect of a substance obtained from polymorphonuclear leucocytes. The Journal of clinical investigation, 27 (4), 524

25. Gery, I., Gershon, R. K., \& Waksman, B. H. (1972). Potentiation of the T-lymphocyte response to mitogens: I. The responding cell. The Journal of experimental medicine, 136 (1), 128-142.

26. Baskaran, N., Manoharan, S., Balakrishnan, S., \& Pugalendhi, P. (2010). Chemopreventive potential of ferulic acid in 7, 12-dimethylbenz [a] anthracene-induced mammary carcinogenesis in Sprague-Dawley rats. European journal of pharmacology, 637 (1-3), 22-29.

27. Murakami, A., Nakamura, Y., Koshimizu, K., Takahashi, D., Matsumoto, K., Hagihara, K., et al.(2002). FA15, a hydrophobic derivative of ferulic acid, suppresses inflammatory responses and skin tumor promotion: comparison with ferulic acid. Cancer Letters, 180 (2), 121-129.

28. Graf, E. (1992). Antioxidant potential of ferulic acid. Free radical biology and medicine, 13 (4), 435-448.

29. Wang, B., \& Trayhurn, P. (2006). Acute and prolonged effects of TNF- $\alpha$ on the expression and secretion of inflammation-related adipokines by human adipocytes differentiated in culture. Pflügers Archiv, 452 (4), 418-427.

30. Hotamisligil, G. S., Peraldi, P., Budavari, A., Ellis, R., White, M. F., \& Spiegelman, B. M. (1996). IRS-1mediated inhibition of insulin receptor tyrosine kinase activity in TNF- $\alpha$-and obesity-induced insulin resistance. Science, 271 (5249), 665-670.

31. Gerin, F., Erman, H., Erboga, M., Sener, U., Yilmaz, A., Seyhan, H., et al. (2016). The effects of ferulic acid against oxidative stress and inflammation in formaldehyde-induced hepatotoxicity. Inflammation, 39(4), 13771386.

32. Szulc-Kielbik, I., Kielbik, M., \& Klink, M. (2017). Ferulic acid but not alpha-lipoic acid effectively protects THP1-derived macrophages from oxidant and pro-inflammatory response to LPS. Immunopharmacology and Immunotoxicology, 39 (6), 330-337.

33. Zhang, S., Wang, P., Zhao, P., Wang, D., Zhang, Y., Wang, J., et al. (2018). Pretreatment of ferulic acid attenuates inflammation and oxidative stress in a rat model of lipopolysaccharide-induced acute respiratory distress syndrome. International journal of immunopathology and pharmacology, 31, 0394632017750518.

34. Mosley, B., Urdal, D. L., Prickett, K. S., Larsen, A., Cosman, D., Conlon, P. J., et al. (1987). The interleukin-1 receptor binds the human interleukin-1 alpha precursor but not the interleukin-1 beta precursor. Journal of biological chemistry, 262 (7), 2941-2944.

35. Kim, B., Lee, Y., Kim, E., Kwak, A., Ryoo, S., Bae, S., et al. (2013). The interleukin-1a precursor is biologically active and is likely a key alarmin in the IL-1 family of cytokines. Frontiers in immunology, 4, 391.

36. Beer, H. D., Contassot, E., \& French, L. E. (2014). The inflammasomes in autoinflammatory diseases with skin involvement. Journal of Investigative Dermatology, 134 (7), 1805-1810. 
37. Gerondakis, S., Grumont, R., Gugasyan, R., Wong, L., Isomura, I., Ho, W., et al. (2006). Unravelling the complexities of the NF-K B signalling pathway using mouse knockout and transgenic models. Oncogene, 25(51), 6781-6799.

38. Hoffmann, A., \& Baltimore, D. (2006). Circuitry of nuclear factor KB signaling. Immunological reviews, 210 (1), 171-186.

39. Kim, E. O., Min, K. J., Kwon, T. K., Um, B. H., Moreau, R. A., \& Choi, S. W. (2012). Anti-inflammatory activity of hydroxycinnamic acid derivatives isolated from corn bran in lipopolysaccharide-stimulated Raw 264.7 macrophages. Food and Chemical Toxicology, 50 (5), 1309-1316.

40. Islam, M. S., Yoshida, H., Matsuki, N., Ono, K., Nagasaka, R., Ushio, H., et al. (2009). Antioxidant, free radical-scavenging, and NF-KB-inhibitory activities of phytosteryl ferulates: structure-activity studies. Journal of pharmacological sciences, 111 (4), 328-337.

41. Nagasaka, R., Chotimarkorn, C., Shafiqul, I. M., Hori, M., Ozaki, H., \& Ushio, H. (2007). Anti-inflammatory effects of hydroxycinnamic acid derivatives. Biochemical and Biophysical Research Communications, 358 (2), 615-619.

42. Hirata, A., Murakamı, Y., Atsumı, T., Shojı, M., Ogıwara, T., Shıbuya, K., et al. (2005). Ferulic acid dimer inhibits lipopolysaccharide-stimulated cyclooxygenase-2 expression in macrophages. In vivo, 19 (5), 849-853.

43. Locksley, R. M., Killeen, N., \& Lenardo, M. J. (2001). The TNF and TNF receptor superfamilies: integrating mammalian biology. Cell, 104(4), 487-501.

44. Akira, S., \& Takeda, K. (2004). Toll-like receptor signalling. Nature reviews immunology, 4 (7), 499-511.

45. Grivennikov, S. I., Tumanov, A. V., Liepinsh, D. J., Kruglov, A. A., Marakusha, B. I., Shakhov, A. N., et al. (2005). Distinct and nonredundant in vivo functions of TNF produced by t cells and macrophages/neutrophils: protective and deleterious effects. Immunity, 22 (1), 93-104.

46. Feldmann, M. (2002). Development of anti-TNF therapy for rheumatoid arthritis. Nature Reviews Immunology, 2 (5), 364-371.

47. Hildebrandt, G. C., Duffner, U. A., Olkiewicz, K. M., Corrion, L. A., Willmarth, N. E., Williams, D. L., et al. (2004). A critical role for CCR2/MCP-1 interactions in the development of idiopathic pneumonia syndrome after allogeneic bone marrow transplantation. Blood, 103 (6), 2417-2426.

48. Billiau, A. (1996). Interferon- $\gamma$ : biology and role in pathogenesis. In Advances in immunology, 62, 61-130.

49. Hayes, M. P., Freeman, S. L., \& Donnelly, R. P. (1995). IFN-y priming of monocytes enhances LPS-induced TNF production by augmenting both transcription and mRNA stability. Cytokine, 7 (5), 427-435.

50. Luster, A. D., \& Ravetch, J. V. (1987). Biochemical characterization of a gamma interferon-inducible cytokine (IP-10). The Journal of experimental medicine, 166 (4), 1084-1097.

51. Xie, Q. W., Whisnant, R., \& Nathan, C. (1993). Promoter of the mouse gene encoding calcium-independent nitric oxide synthase confers inducibility by interferon gamma and bacterial lipopolysaccharide. The Journal of experimental medicine, 177(6), 1779-1784.

52. Tamura, T., Ueda, S., Yoshida, M., Matsuzaki, M., Mohri, H., \& Okubo, T. (1996). Interferon-Y InducesIceGene Expression and Enhances Cellular Susceptibility to Apoptosis in the U937 Leukemia Cell Line. Biochemical and biophysical research communications, 229(1), 21-26.

53. Cheshire, J. L., \& Baldwin, A. S. (1997). Synergistic activation of NF-kappaB by tumor necrosis factor alpha and gamma interferon via enhanced I kappaB alpha degradation and de novo I kappaBbeta degradation. Molecular and cellular biology, 17 (11), 6746-6754.

54. Schroder, K., Hertzog, P. J., Ravasi, T., \& Hume, D. A. (2004). Interferon-y: an overview of signals, mechanisms and functions. Journal of leukocyte biology, 75 (2), 163-189.

55. Moore, K. W., Vieira, P., Fiorentino, D. F., Trounstine, M. L., Khan, T. A., \& Mosmann, T. R. (1990). Homology of cytokine synthesis inhibitory factor (IL-10) to the Epstein-Barr virus gene BCRFI. Science, 248 (4960), 1230-1234.

56. Umetsu, S. E., \& Winandy, S. (2009). Ikaros is a regulator of Il10 expression in CD4+ T cells. The Journal of Immunology, $183(9), 5518-5525$. 